\title{
Effect of soil bulk density on forest tree seedlings**
}

\author{
Mariusz Kormanek ${ }^{1 *}$, Jacek Banach ${ }^{2}$, and Pawet Sowa ${ }^{1}$ \\ ${ }^{1}$ Department of Forest Work Mechanization, ${ }^{2}$ Department of Genetics and Forest Tree Breeding, \\ University of Agriculture in Cracow, Al. 29 listopada 46, 31-423 Cracow, Poland \\ Received March 14, 2013; accepted February 3, 2014
}

\begin{abstract}
A b s t r a c t. The paper presents the results of an analysis of the influence of soil bulk density in a forest nursery plot on the growth and quality parameters of Scots pine and European beech seedlings. Particular density variants were obtained using a tractor device exerting controlled pressure on the soil, while field examinations were performed on an area of 'Kłaj' forest nursery in Niepołomice Forest District. Three series of plots were prepared for each species, applying a unit pressure of the values of $50,100,150,200,250 \mathrm{kPa}$, corresponding to the dry bulk density in the range of $1.03-1.19 \mathrm{~g} \mathrm{~cm}^{-3}$, and control plots without the pressure. Seeds of the examined species were sown on the prepared plots, and after 6 months of growth the seedlings were subjected to biometric analysis determining differentiation in root neck diameter, length of the above-ground part and root system, as well as dry mass of particular parts of the plant. The quality of the seedlings was also determined using the method of Schmidt-Vogt. The results obtained show that the change in dry bulk density soil significantly affected most of the growth parameters of the examined seedlings. Especially high negative correlations were obtained for the length and dry mass of the root system. A significant influence of dry bulk density variant on all growth parameters of Scots pine seedlings, and on some parameters of European beech was demonstrated. An increase in soil bulk density clearly caused also a deterioration of European beech seedlings quality.

K e y w or d s: bulk density, seedling parameters, quality, Scots pine, European beech
\end{abstract}

\section{INTRODUCTION}

Large number of machines and agricultural vehicles moving over fields contributes to undesirable changes in the form of an increased soil compaction (Głąb, 2013; Lipiec et al., 2003). Crop yield decrease is considered as the best

\footnotetext{
*Corresponding author e-mail: kormanek@wp.pl

**This work was founded by the Ministry of Science and Higher Education with the 2011 budget for statutory activities (DS-3401/ KMPL/2011 and DS-3405/ZGNiSzL/2011).
}

recognized and direct effect of compaction (Whalley et al., 2008), however the relationship between soil compaction and yield is not direct due to the occurrence of interactions with soil kind, as well as with water and air presence. There are some reports indicating a positive effect of soil compaction, ie an increase in crop yield on the compacted soil (Bejarano et al., 2010; Frost, 1998), which may be connected to the type of root system and ability of compacted soil penetration (Chen and Weil, 2010). Bulk density is one of the parameters frequently used to characterize soil compaction level and its effect on the yields (Alameda et al., 2012; Hamza and Anderson, 2005, Zhao et al., 2010). Obtained relationships between soil bulk density and species of plants growing on that soil are often divergent and difficult for generalization. It was noted, however, that the same kind of soil should be treated in a manner allowing to obtain an optimum density for the cultivated plant species (Kopeć and Głąb, 2006; Lipiec et al., 2003).

Production of seedlings in forest nurseries, where oneyear, or a few years old seedlings of forest trees and bushes aimed at various purposes are produced, is comparable to agricultural plants cultivation. The same problems with compaction of soils, usually caused by the same type of machines, occurs in nursery production, as in agricultural production. It is usually assumed that the conditions of seedling material production should be possibly the most consistent with those of further growing. Thus, soil importance is high in seedlings cultivation, since it is a source of mineral components, ensures proper conditions for plants development and soil organisms living. Different quality of particular soil horizons may be of a high significance in seedlings

(C) 2015 Institute of Agrophysics, Polish Academy of Sciences 
production in nurseries. Also good organization and production technology are important in order to obtain high quality of nursery material (Wesoły and Hauke, 2009). Soil density caused by multiple passage of machines affects soil physical, chemical and biological quality in agricultural and nursery production, as well as in forest production, which is a reason of numerous negative phenomena. Fertilizers are absorbed in a poorer manner, and various chemical compounds stay in the soil for a longer time, which leads to environment pollution and increased costs of plant production. Too compacted a soil loses its ability of infiltration and prevents rainwater storage, which causes fast water flow and soil erosion (Cudzik et al., 2010). Soil compaction caused by multiple tractor units passing through the farm fields can cause shallow rooting of the plants and changes in roots morphological features (Bartholomew and Williams, 2010; Głąb, 2013; Lipiec et al., 2003; 2012a,b; Powałka, 2008), while oxygen deficit in the soil is a reason of plants growth suppression (Balakhnina et al., 2012). The intensity and kind of cultivation which affect soil structure have also a significant meaning for microbiological activity or organic compounds content in the soil (Blouin et al., 2008; Gajda and Przewłoka, 2012; Sławiński et al., 2012). Plants growing in compacted soil conditions are characterized by lower vitality, shallower root system developing towards upper soil layers more saturated with an air (Chen and Weil, 2011). Shallow root system influences the stability of trees in the forest (Ulrich et al., 2003). In 2002, the European Commission accepted soil density as one of the eight main threats for the environment and plant development (Lipiec and Hatano, 2003; Rejman and Usowicz, 2002). In turn, growth parameters of seedlings obtained in the nursery are significant both as regards production economics and also the health status of the forest formed of cultivated seedlings. In this case there is a need of optimization of interactions between soil, plant and machine, and focusing on such solutions which would allow to obtain high yields which satisfy the economic conditions of nursery production (Lipiec et al., 2003). The issue of the influence of soil density on the forest environment is still tested due to the complexity of the problem and the numerous factors and interactions related to forest production, including ecological and economic aspects (Ampoorter et al., 2007; Blouin et al., 2008; Picchio et al., 2012; Tan et al., 2006). Also, research is conducted in the range of the influence of soil density on forest trees species seedlings cultivated in forest nurseries (Blouin et al., 2008; Cubera et al., 2009; Onweremadu et al., 2008; Zhao et al., 2010).

The research problem undertaken in this study concerned the determination of the relationship between dry soil bulk density on nursery plot and growth parameters, as well as quality of cultivated seedlings of two important forest forming species, ie Scots pine (Pinus sylvestris L.) and European beech (Fagus sylvatica L.).

\section{MATERIALS AND METHODS}

The experimental plots, the soil on which was characterized by various compaction obtained by an artificial unit pressure of different values $(50,100,150,200,250 \mathrm{kPa})$ exerting, were prepared in the study. An original device, mounted on a universal tractor, was used in the study for the purpose of exerting controlled unit pressure the soil (Kormanek and Banach, 2011; 2012) (Fig. 1).

The device is constructed of a main frame mounted on a standard lower swinging drawbar of the universal tractor. It is placed symmetrically between the tractor rear wheels. The connection between the frame of the device and the swinging drawbar is realized using bolts put through the holes in the swinging drawbar and the frame of the device, which enables easy and quick connection of both elements.

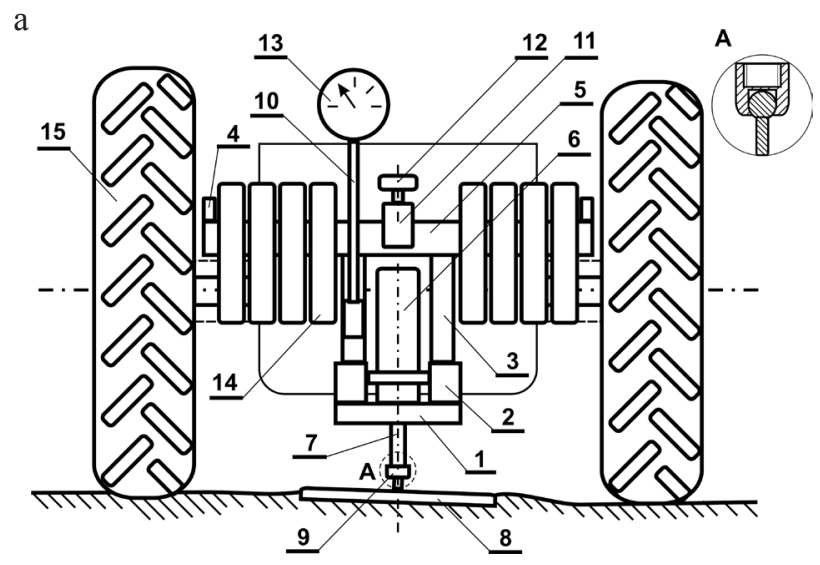

b

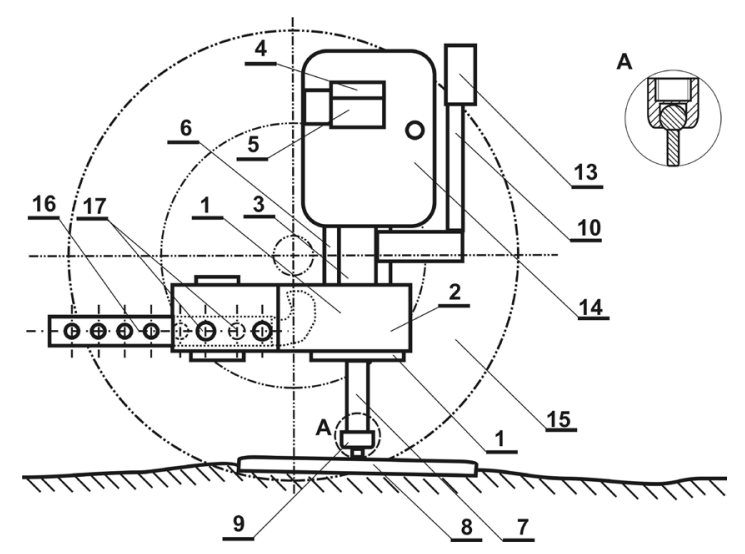

Fig. 1. Tractor device for exerting controlled pressure on the soil: $\mathrm{a}$ - front view, $\mathrm{b}$ - side view; 1,2 - main frame of the device, 3,5 - elements of extenders frame, 4 - protection against extenders sliding down, 6 - hydraulic cylinder, 7 - hydraulic cylinder rod, 8 - stump, 9 - connecting joint, 10 - manometer boom, 11 - oil pressure regulating valve, 12 - knob of oil pressure regulating valve, 13 - manometer, 14 - extenders, 15 - tractor wheels, 16 - swinging drawbar, 17 - bolts of device fixing. A - crosssection of the connection. 
The body of hydraulic cylinder is fixed vertically to the element of main frame. The elements of extender frame which are fixed above the main frame are for standard tractor extenders. The compacting stump is fixed to the rod of the hydraulic cylinder using ball joints (extension A on Fig. 1). The manometer boom is placed at a side of extenders frame and a measuring manometer, demonstrating the pressure in the hydraulic system of the research device, is fixed on it. Extenders are protected against sliding down by element. The hydraulic system developed is composed of hydraulic cylinder, a measuring manometer for pressure control, and a valve for its regulation by means of a knob, which allows to establish the pressure value and thus the force exerted on the stump by hydraulic cylinder rod. The hydraulic system of the device is connected to the system of external hydraulics of the tractor via push-in fittings.

The values of unit pressure were selected so that they cause various soil bulk densities on nursery plot, and concurrently not diverge from the values which may be caused by the machines which move on soil surface during nursery works. The pressure was exerted for eight seconds, which corresponds to the time of pressure exerted by two elements of running gear of a vehicle, eg tractor wheel, which moves four times over the plot surface with the working speed of about $0.7 \mathrm{~m} \mathrm{~s}^{-1}$ (four-wheel vehicle whose wheels move in succession, with a length of single wheel contact with bedding of about $0.7 \mathrm{~m}$ ). The number of passages of the vehicles over the plot was selected according to Kroulík et al. (2009). The experiment was localized on the area of 'Kłaj' forest nursery (Niepołomice Forest District), and a fragment of nursery plot with a width of 1.2 and length of $115 \mathrm{~m}$ was selected for the study. A flat, square panel of the size of $0.2 \times 0.3 \mathrm{~m}$ was used as a punch.

The experiment with six bulk density levels ( 5 variants of pressure and control without the pressure) in three replications was prepared for each of the examined species. Thirty six plots were prepared in total, and they were then sown with the seeds (4th April 2010) and covered with the soil, using covering thickness corresponding to the size of seeds (Wesoły and Hauke, 2009). The same number of seeds was sown on each plot within particular species, ie 100 seeds for Scots pine and 50 for European beech. The growth of the seedlings was controlled during the whole vegetation cycle, and essential nursery practices, $i e$ watering, covering with shadowing net, weeding, were performed in case of need. After six months (8th October) the plants were dug up with root clump and transported to the laboratory. During plants preparation for the measurements, the root with soil was steeped in a container with water. Then single seedlings were obtained after carefully clearing the root system with running water and drying it. After that, the length of the above-ground part and root system was measured, as well as the root neck diameter of each seedling. Then the seedlings were dried at a temperature of $70^{\circ} \mathrm{C}$ for $48 \mathrm{~h}$, and dry mass of above-ground part, root system and dry mass of assimilation apparatus were determined separately for each seedling. The data obtained were subjected to statistical analysis using STATISTICA 9.0 software. Mean values of analyzed features were calculated, diagrams of the changes depending on the value of bulk density resulting from pressure exerted were prepared, and correlations between bulk density and seedling parameters, significance of the influence of bulk density on differentiation of the values of parameters in particular measurement variants were calculated using one-factor analysis of variance. Also the quality of cultivated seedlings was assessed using the method proposed by Schmidt-Vogt (Kormanek and Banach, 2012) which is based on a linear relationship of root neck diameter and height of and seedlings, and is expressed by the following equation:

calculated root neck diameter $(\mathrm{mm})=$ stalk length $(\mathrm{cm}) \mathrm{R}+\mathrm{Z}$

where: $\mathrm{R}$ is reduction factor which depends on the species, while $\mathrm{Z}$ is so called 'excess' which determines how much above the line presenting function relationship between both parameters is the value for a given species. The quality for each seedling (good quality or poor quality) was determined by the comparison of seedling diameter calculated from the formula and measured thickness.

Soil samples in an undisturbed form were also collected on the nursery plot from extra prepared plots (5 variants of pressure and control without the pressure, in three replications). Extra plots were placed randomly between the plots with seedlings. Soil samples were collected from each of the 18 plots to measuring cylinders of a volume of $250 \mathrm{~cm}^{3}$ from $0-10 \mathrm{~cm}$ depth, in order to determine the mechanical composition, volumetric water content and dry bulk density. Also organic carbon and nitrogen content was determined using a LECO TruMac CNS 2000 analyzer.

\section{RESULTS AND DISCUSSION}

The experiment was performed on soil composed mainly of sand with silt and clay (Table 1) which may be classified as sandy loam. Compost addition was used on the soil in previous years, and thus dry bulk density on the control surfaces was relatively low (Table 2). The level of organic carbon determined in soil samples collected on the plot was $\mathrm{C}=4.856 \%$ while nitrogen level was $\mathrm{N}=0.344 \%$.

Dry soil bulk density increased with an increase in the value of unit pressure, while volumetric water content and porosity decreased, ie soil condenzation with concurrent water pushing up into deeper soil horizons was observed (Table 2).

The percentage of one-year seedlings obtained in the experiment was very differentiated and depended on the species. For Scots pine, on average $67.1 \%$ of seedlings were obtained from all of seeds sown, while for the European beech this value was $38.4 \%$ (Table 2). This is a level proper for the pine which, according to Wesoly and Hauke (2009), should be $70 \%$ on average for soil nurseries, while slightly 
T a b l e 1. Mechanical composition of the soil on the plot in nursery

\begin{tabular}{cccccccccc}
\hline & \multicolumn{4}{c}{ Diameter $(\mathrm{mm})$} & & \multicolumn{2}{c}{ Fraction name } \\
\hline & $1-0.1$ & $0.1-0.05$ & $0.05-0.02$ & $\begin{array}{c}0.02- \\
0.006\end{array}$ & $\begin{array}{c}0.006- \\
0.002\end{array}$ & $<0.002$ & sand & silt \\
\hline Share (\%) & 75 & 4 & 10 & 6 & 3 & 2 & 75 & 14 & 11 \\
\hline
\end{tabular}

T a b l e 2. Mean dry bulk density of the collected soil samples and number of cultivated seedlings in particular pressure variants

\begin{tabular}{|c|c|c|c|c|c|c|c|}
\hline \multirow{3}{*}{$\begin{array}{l}\text { Unit pressure } \\
\qquad(\mathrm{kPa})\end{array}$} & \multirow{3}{*}{$\begin{array}{c}\text { Volumetric } \\
\text { water content } \\
(\%)\end{array}$} & \multirow{3}{*}{$\begin{array}{l}\text { Dry bulk } \\
\text { density } \\
\left(\mathrm{g} \mathrm{cm}^{-3}\right)\end{array}$} & \multirow{3}{*}{$\begin{array}{c}\text { Porosity } \\
(\%)\end{array}$} & \multicolumn{4}{|c|}{ Number of seedlings of analyzed species } \\
\hline & & & & \multicolumn{2}{|c|}{ Scots pine } & \multicolumn{2}{|c|}{ European beech } \\
\hline & & & & pieces & $\%$ & pieces & $\%$ \\
\hline $\begin{array}{l}\text { Control } \\
\text { (without } \\
\text { pressure) }\end{array}$ & $27.8 \pm 1.65$ & $1.02 \pm 0.010$ & $19.2 \pm 0.4$ & 180 & 60.0 & 64 & 42.7 \\
\hline 50 & $29.0 \pm 1.01$ & $1.03 \pm 0.014$ & $18.9 \pm 1.1$ & 167 & 55.7 & 58 & 38.7 \\
\hline 100 & $29.1 \pm 0.35$ & $1.11 \pm 0.041$ & $13.9 \pm 3.2$ & 246 & 82.0 & 53 & 35.3 \\
\hline 150 & $29.0 \pm 0.64$ & $1.14 \pm 0.063$ & $12.5 \pm 4.9$ & 262 & 87.3 & 61 & 40.7 \\
\hline 200 & $27.8 \pm 1.65$ & $1.15 \pm 0.014$ & $11.1 \pm 1.1$ & 191 & 63.7 & 40 & 26.7 \\
\hline \multirow[t]{2}{*}{250} & $26.4 \pm 0.60$ & $1.19 \pm 0.015$ & $7.1 \pm 1.0$ & 163 & 54.3 & 70 & 46.7 \\
\hline & Total & & & 1209 & 67.1 & 346 & 38.4 \\
\hline
\end{tabular}

T a b l e 3. Average values of growth parameters of analyzed seedlings

\begin{tabular}{|c|c|c|c|c|}
\hline \multirow[b]{2}{*}{ Species } & \multirow{2}{*}{$\begin{array}{l}\text { Dry bulk density } \\
\qquad\left(\mathrm{g} \mathrm{cm}^{-3}\right)\end{array}$} & \multicolumn{3}{|c|}{ Parameter } \\
\hline & & $\begin{array}{l}\text { length of seedling } \\
(\mathrm{cm})\end{array}$ & $\begin{array}{l}\text { length of root system } \\
(\mathrm{cm})\end{array}$ & $\begin{array}{l}\text { diameter in root neck } \\
(\mathrm{mm})\end{array}$ \\
\hline \multirow{6}{*}{ Scots pine } & 1.02 & $20.5 \pm 3.9$ & $15.0 \pm 3.5$ & $0.9 \pm 0.3$ \\
\hline & 1.03 & $15.9 \pm 3.2$ & $9.6 \pm 2.4$ & $1.0 \pm 0.3$ \\
\hline & 1.11 & $18.0 \pm 4.3$ & $11.4 \pm 4.1$ & $1.1 \pm 0.3$ \\
\hline & 1.14 & $14.2 \pm 2.6$ & $7.8 \pm 1.9$ & $1.0 \pm 0.3$ \\
\hline & 1.15 & $15.0 \pm 3.4$ & $8.7 \pm 2.8$ & $0.9 \pm 0.3$ \\
\hline & 1.19 & $14.0 \pm 2.6$ & $7.8 \pm 1.7$ & $0.8 \pm 0.2$ \\
\hline \multirow{6}{*}{ European beech } & 1.02 & $43.2 \pm 11.1$ & $23.2 \pm 7.1$ & $4.4 \pm 1.0$ \\
\hline & 1.03 & $44.1 \pm 9.1$ & $23.5 \pm 5.5$ & $4.3 \pm 1.0$ \\
\hline & 1.11 & $43.9 \pm 12.1$ & $22.8 \pm 7.2$ & $4.3 \pm 1.0$ \\
\hline & 1.14 & $42.7 \pm 9.8$ & $21.1 \pm 4.7$ & $4.2 \pm 1.1$ \\
\hline & 1.15 & $40.2 \pm 9.8$ & $20.6 \pm 5.2$ & $4.0 \pm 1.2$ \\
\hline & 1.19 & $38.6 \pm 9.5$ & $18.1 \pm 4.2$ & $4.0 \pm 1.1$ \\
\hline
\end{tabular}


too low for the beech $-60 \%$ on average. The relatively low sowing yield was affected by the low sowing value of the seeds; it was not possible to sow more of them due to small size of the plot.

The highest average value of root system and whole seedling length in the case of Scots pine was obtained for the control plots (without the pressure), while in the case of European beech for the variant in which pressure of a value of $50 \mathrm{kPa}$ was exerted. The lowest mean values for the length of whole seedlings as well as for root system for both species were obtained with the highest pressure $(250 \mathrm{kPa})$, ie with soil density at the level of $1.19 \mathrm{~g} \mathrm{~cm}^{-3}$ (Table 3, Fig. 2). Such a change of parameters of seedlings was most likely the result of decrease of porosity caused by increasing level of exerted unit pressure (Table 2) (Lipiec et al., 2012).

Decreasing tendency for root system length with an increase in the level of soil bulk density is confirmed by the slopes of trend lines of regression equation determined for both analyzed species (Fig. 2), while correlation coefficients in both cases appear to be significant on an accepted significance level (Table 4). Similar tendencies of changes during

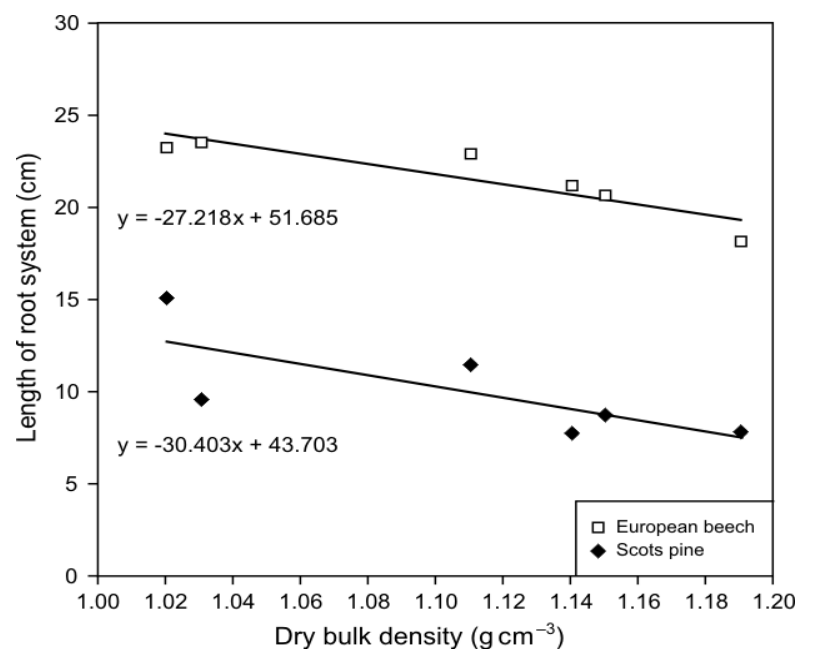

Fig. 2. Length of root system of the seedlings depending on soil dry bulk density. laboratory examinations were obtained by Bejarano et al. (2010) who examined Quercus pyreneica, or Onweremadu et al. (2008) who analyzed the influence of soil bulk density and humidity on the seedlings of Citrus sinensis.

Mean dry mass of root system in the case of pine also decreased with an increase in soil bulk density (Table 5, Fig. 3), while for beech the maximum level of dry mass was observed with unit pressure at the level of $100 \mathrm{kPa}$, which corresponded to bulk density of $1.11 \mathrm{~g} \mathrm{~cm}^{-3}$. This suggests that conditions of low soil compaction are more favourable for beech, which is consistent with the results of a previous study conducted under canopy (Kormanek and Banach, 2012).

Root system shortening and decrease in its dry mass prove the difficulties which plants faced growing on increasingly compacted soil. Increasing soil bulk density caused also a decrease in root neck diameter in both species, as well as a decrease in the whole seedling length and its dry mass (Tables 3-5). Similar significant negative correlations between soil bulk density increase and seedling length were obtained by Cubera et al. (2009) who examined seedlings of Quercus ilex, and also by Bejarano et al. (2010)

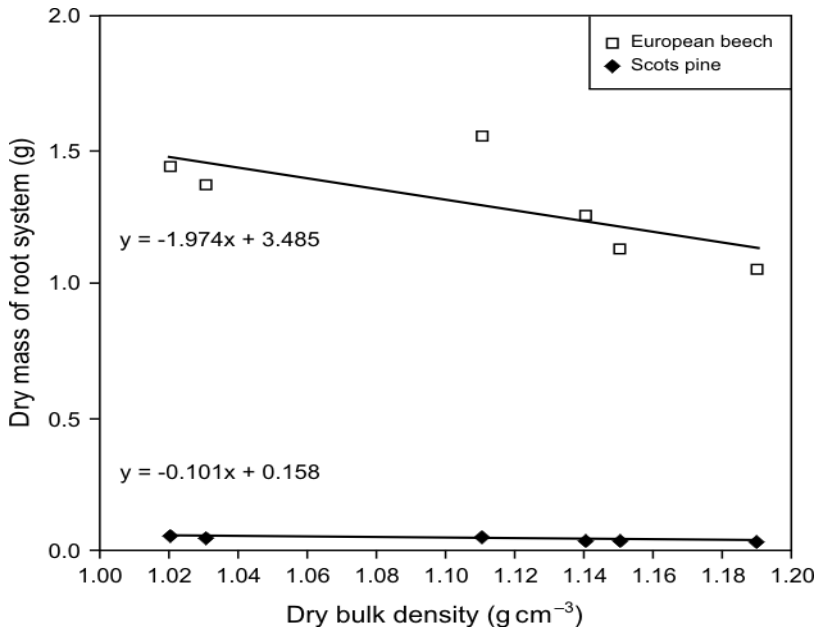

Fig. 3. Dry mass of root system of the seedlings depending on soil dry bulk density.

T a b l e 4. Correlations between the value of pressure exerted and measured parameters of seedlings

\begin{tabular}{lcccccccc}
\hline & \multicolumn{3}{c}{ Length } & & & & \multicolumn{2}{c}{ Dry mass } \\
\cline { 2 - 3 } Species & $\begin{array}{c}\text { whole } \\
\text { seedling }\end{array}$ & root system & $\begin{array}{c}\text { above- } \\
\text { ground part }\end{array}$ & $\begin{array}{c}\text { Diameter in } \\
\text { root neck }\end{array}$ & $\begin{array}{c}\text { above- } \\
\text { ground part }\end{array}$ & root system & $\begin{array}{c}\text { whole } \\
\text { seedlings }\end{array}$ & $\begin{array}{c}\text { leafs } \\
\text { or needles }\end{array}$ \\
\hline Scots pine & $-0.410^{*}$ & $-0.744^{*}$ & $0.161^{*}$ & $-0.083^{*}$ & -0.024 & $-0.241^{*}$ & $-0.133^{*}$ & $-0.109^{*}$ \\
$\begin{array}{l}\text { European } \\
\text { beech }\end{array}$ & $-0.157^{*}$ & $-0.297^{*}$ & 0.026 & $-0.113^{*}$ & -0.048 & $-0.174^{*}$ & $-0.109^{*}$ & -0.028 \\
\hline
\end{tabular}

*Correlation coefficients significant at $\mathrm{p}<0.05$. 
T a b l e 5. Mean values of dry mass of the examined seedlings

\begin{tabular}{|c|c|c|c|c|c|}
\hline \multirow{2}{*}{ Species } & \multirow{2}{*}{$\begin{array}{l}\text { Dry bulk density } \\
\qquad\left(\mathrm{g} \mathrm{cm}^{-3}\right)\end{array}$} & \multicolumn{4}{|c|}{ Dry mass (g) } \\
\hline & & whole seedling & root system & above-ground part & leafs/needles \\
\hline \multirow{6}{*}{ Scots pine } & 1.02 & $2.958 \pm 0.091$ & $0.058 \pm 0.028$ & $0.042 \pm 0.020$ & $0.207 \pm 0.050$ \\
\hline & 1.03 & $2.948 \pm 0.085$ & $0.045 \pm 0.022$ & $0.045 \pm 0.021$ & $0.208 \pm 0.051$ \\
\hline & 1.11 & $2.970 \pm 0.090$ & $0.055 \pm 0.026$ & $0.053 \pm 0.023$ & $0.211 \pm 0.050$ \\
\hline & 1.14 & $2.930 \pm 0.088$ & $0.040 \pm 0.022$ & $0.044 \pm 0.022$ & $0.195 \pm 0.051$ \\
\hline & 1.15 & $2.942 \pm 0.103$ & $0.042 \pm 0.024$ & $0.045 \pm 0.025$ & $0.204 \pm 0.058$ \\
\hline & 1.19 & $2.909 \pm 0.069$ & $0.034 \pm 0.016$ & $0.038 \pm 0.021$ & $0.187 \pm 0.038$ \\
\hline \multirow{6}{*}{ European beech } & 1.02 & $3.070 \pm 1.484$ & $1.437 \pm 0.753$ & $1.005 \pm 0.513$ & $0.628 \pm 0.350$ \\
\hline & 1.03 & $3.036 \pm 1.533$ & $1.374 \pm 0.747$ & $0.976 \pm 0.476$ & $0.686 \pm 0.422$ \\
\hline & 1.11 & $3.301 \pm 1.429$ & $1.553 \pm 0.732$ & $0.959 \pm 0.455$ & $0.789 \pm 0.372$ \\
\hline & 1.14 & $2.915 \pm 1.494$ & $1.254 \pm 0.707$ & $0.982 \pm 0.509$ & $0.679 \pm 0.408$ \\
\hline & 1.15 & $2.741 \pm 1.397$ & $1.128 \pm 0.620$ & $0.930 \pm 0.496$ & $0.683 \pm 0.387$ \\
\hline & 1.19 & $2.566 \pm 1.507$ & $1.056 \pm 0.680$ & $0.920 \pm 0.596$ & $0.590 \pm 0.363$ \\
\hline
\end{tabular}

T a b l e 6. Results of analysis of variance of differences between mean values determined for particular parameters (value of $F$ test and significance level p)

\begin{tabular}{|c|c|c|c|c|c|c|c|c|}
\hline \multirow[b]{2}{*}{ Species } & \multicolumn{3}{|c|}{ Length } & \multirow{2}{*}{$\begin{array}{c}\text { Diameter } \\
\text { in root neck }\end{array}$} & \multicolumn{4}{|c|}{ Dry mass } \\
\hline & $\begin{array}{c}\text { whole } \\
\text { seedling }\end{array}$ & root system & $\begin{array}{c}\text { above- } \\
\text { ground part }\end{array}$ & & $\begin{array}{l}\text { above- } \\
\text { ground part }\end{array}$ & root system & $\begin{array}{c}\text { whole } \\
\text { seedlings }\end{array}$ & $\begin{array}{c}\text { leafs } \\
\text { or needles }\end{array}$ \\
\hline \multirow[t]{2}{*}{ Scots pine } & 106.627 & 166.294 & 25.020 & 13.410 & 10.391 & 30.526 & 11.221 & 6.227 \\
\hline & \multicolumn{8}{|c|}{$\mathrm{p}<0.001$} \\
\hline \multirow{2}{*}{$\begin{array}{l}\text { European } \\
\text { beech }\end{array}$} & 2.764 & 8.195 & 0.700 & 1.201 & 0.236 & 4.034 & 1.787 & 1.787 \\
\hline & $p=0.018$ & $\mathrm{p}<0.001$ & $\mathrm{p}=0.624$ & $\mathrm{p}=0.308$ & $\mathrm{p}=0.946$ & $p=0.001$ & $p=0.115$ & $p=0.115$ \\
\hline
\end{tabular}

$\mathrm{p}$ value in bold indicates $\mathrm{p}<0.05$.

on Quercus pyreneica and by Zhao et al. (2010) analysing seedlings of Pseudotsuga menziesii, Pinus contorata and the crossbred of Picea glauca and Picea engelmannii. This was also confirmed by Blouin et al. (2008), who demonstrated a negative relationship between the level of bulk density and height as well as dry mass of seedlings of $P$. contorta.

A confirmation of a significant influence of soil bulk density on seedlings growth was an analysis of variance performed for their particular parameters (Table 6). In the case of pine, especially strong differentiation for the whole seedling length, root system length, length of the above-ground part as well as root neck diameter and root system dry mass resulting from the change in soil density was demonstrated.
For the beech, the differentiation appeared to be significant for the length of root system, whole seedling length and root system dry mass.

Decrease in the whole seedlings length and root neck diameter with increase of soil bulk density affected their quality assessment (Fig. 4). For the beech, the percentage of good quality seedlings decreased definitely, from the level of $87.5 \%$ with low soil density to $68.6 \%$ with high soil bulk density. In the case of pine, the highest percentage of good quality seedlings $(3.3 \%)$ was obtained with bulk density at the level of $1.11 \mathrm{~g} \mathrm{~cm}^{-3}$. The generally low quality of pine seedlings could have been an effect of abiotic factors, especially abundant precipitations which caused poorer development of already shallow rooted seedlings. 
a

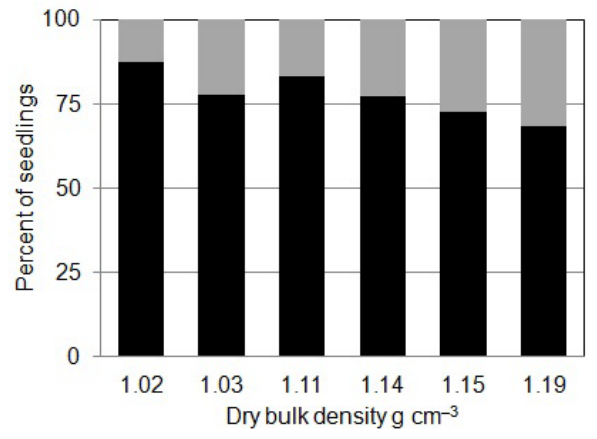

b

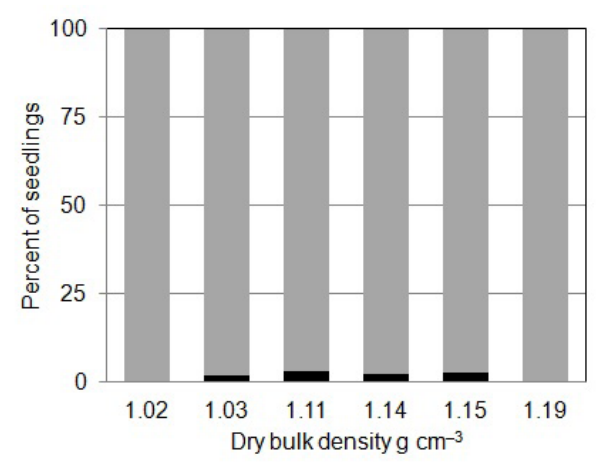

Fig. 4. Percentage of good quality $(\square$ ) and poor quality $(\square$ ) of seedlings for: a - European beech and b - Scots pine assessed according to Schmidt-Vogt classification.

Generally, the experiment demonstrated minor differences in bulk density between the variants of exerted unit pressure determined on soil samples collected with the use of measuring cylinders, while the variability of most of the seedlings parameters was statistically significant. Change of soil bulk density and porosity probably concerned only the top layer of soil directly under the stump, which resulted in the process of germination and initial growth of seedlings. Thus, in order to determine the influence of applied pressure on the bulk density of soil a different method of measurements should be applied, taking into account only the analysis of the top layer of soil.

\section{CONCLUSIONS}

1. The results obtained indicate a significant negative correlation between an increase in dry soil bulk density and the length as well as dry mass of seedlings root system, and the whole seedlings length and dry mass, and also a positive significant correlation between an increase in bulk density and root neck diameter in the case of Scots pine.

2. Significant differentiation between the variants of dry bulk density was demonstrated for all examined growth parameters in the case of Scots pine, and for parameters of root length, whole seedling length and root system dry mass in the case of European beech.

3. The share of seedlings with a proper height to root neck thickness ratio, determined using Schmidt-Vogt method, was differentiated depending on the species. Nearly $98 \%$ of the obtained Scots pine seedlings did not fulfil the assumed criterion and was classified as poor quality seedlings, while in the case of European beech, almost $78 \%$ of the seedlings fulfilled the assumed criterion and were classified as good quality ones.

4. Deterioration in seedlings quality, determined using Schmidt-Vogt method, was observed with an increase in dry soil bulk density on nursery plot, especially in the case of European beech seedlings, while the results obtained for the Scots pine suggest that the seedlings of various species may require dry soil bulk density in a specified range for optimum growth on nursery plot. This observation needs hoverer to be confirmed in further research for other species and with a larger spectrum of dry soil bulk density variants in the nursery.

\section{REFERENCES}

Alameda D., Anten N.P.R., and Villar R., 2012. Soil compaction effects on growth and root traits of tobacco depend on light, water regime and mechanical stress. Soil Till. Res., 120, 121-129.

Ampoorter E., Goris R., Cornelis W., M., and Verheyen K., 2007. Impact of mechanized logging on compaction status of sandy forest soils. Forest Ecol. Manag., 241, 162-174.

Balakhnina T., Bennicelli R., Stępniewska Z., Stępniewski W., Borkowska A., and Fomina I., 2012. Stress responses of spring rape plants to soil flooding. Int. Agrophys., 26, 347-353.

Bartholomew P.W. and Williams R.D., 2010. Effects of soil bulk density and strength on seedling growth of annual ryegrass and tall fescue in controlled environment. Grass Forage Sci., 65, 348-357.

Bejarano M.D., Villar R., Murillo A.M., and Quero J.L., 2010. Effects of soil compaction and light on growth of Quercus pyrenaica Willd. (Fagaceae) seedlings. Soil Till. Res., 110, 108-114.

Blouin V. M., Schmidt M.G., Bulmer C.E., and Krzic M., 2008. Effects of compaction and water content on lodgepole pine sidling growth. Forest Ecol. Manag., 255, 2444-2452.

Chen G. and Weil R., 2010. Penetration of cover crop roots through compacted soils. Plant Soil, 331, 31-43.

Chen G. and Weil R., 2011. Root growth and yield of maize as affected by soil compaction and cover crops. Soil Till. Res., 117, 17-27.

Cubera E., Moreno G., and Solla A., 2009. Quercus ilex root growth in response to heterogeneous conditions of soil bulk density and soil $\mathrm{NH}_{4}-\mathrm{N}$ content. Soil Till. Res., 103, 16-22.

Cudzik A., Białczyk J., Czarnecki J., and Jamrozy K., 2010. Traction properties of the wheel-turfy soil system. Int. Agrophys., 24, 343-350.

Gajda A.M. and Przewłoka B., 2012. Soil biological activity as affected by tillage intensity. Int. Agrophys., 26, 15-23.

Gląb T., 2013. Impact of soil compaction on root development and yield of meadow-grass. Int. Agrophys., 27, 7-13. 
Guihua C. and Weil R.R., 2010. Penetration of cover crop roots through compacted soils. Plant Soil, 331, 31-43.

Hamza M.A. and Anderson W.K., 2005. Soil compaction in cropping systems. A review of the nature, causes and possible solutions. Soil Till. Res., 82, 121-145.

Kopeć S. and Gląb T., 2006. The influence of soil compaction on yielding of selected species of grass (in Polish). Scientific papers of the University of Life Sciences, Agriculture, 88(545), 141-146.

Kormanek M. and Banach J., 2011. Tractor devices to controlled exerting pressure on the soil - building and use. In: Mobile energy systems -Hydraulics -Environment-Ergonomics of mobile machines. Peer - reviewed Proceedings. Technical University in Zvolen, Slovakia.

Kormanek M. and Banach J., 2012. Influence of unit pressure exerted on soil on quality of renovation of chosen species of trees (in Polish). Acta Agrophysica, 19(1), 51-63.

Kroulík M., Kumhála F., Húla J., and Honzík I., 2009. The evaluation of agricultural machines field trafficing intensity for different soil tillage technologies. Soil Till. Res., 105, 171-175.

Lipiec J., Hajnos M., and Świeboda R., 2012a. Estimating effects of compaction on pore size distribution of soil aggregates by merkury porosimeter. Geoderma, 179-180, 20-27.

Lipiec J., Horn R., Pietrusiewicz J., and Siczek A., 2012b. Effects of soil compaction on root elongation and anatomy of different cereal plant species. Soil Till. Res., 121, 74-81.

Lipiec J. and Hatano R., 2003. Quantification of compaction effects on soil physical properties and crop growth. Geoderma, 16, 107-136.

Lipiec J., Medvedev V.V., Birkas M., Dumitru E., Lyndina T.E., Rousseva S., and Fulajtar E., 2003. Effect of soil compaction on the root growth and crop yield in Central and Eastern Europe. Int. Agrophysics, 17, 61-69.
Onweremadu E.U., Eshett E.T., Ofoh M.C., Nwufo M.I., and Obiefuna J.C., 2008. Seedling performance as affected by bulk density and soil moisture on a Typic Tropaquept. J. Plant Sci., 3(1), 43-51.

Picchio R., Neri F., Petrini E., Verani S., Marchi E., Certini G., 2012. Machinery-induced soil compaction in thinning two pine stands in central Italy. Forest Ecol. Manag., 285, $38-43$.

Powalka M., 2008. Changes in topsoil properties due to wheel pressure forces generated by tractor units (in Polish). Inżynieria Rolnicza, 1(99), 339-343.

Rejman J. and Usowicz B., 2002. Evaluation of soil-loss contribution areas on loess soils in southeast Poland. Earth Surface Processes Landforms, 27, 1415-1423.

Sławiński C., Cymerman J., Witkowska-Walczak B., and Lamorski K., 2012. Impact of diverse tillage on soil moisture dynamics. Int. Agrophys., 26, 301-309.

Ulrich R., Neruda J., and Valenta J., 2003. Influence of chosen machine carriage systems on soil. (in Polish). Inżynieria Rolnicza, 11(53), 229-235.

Wesoły W. and Hauke M., 2009. Forest nursery from A to Z (in Polish). State Forests Information Centre, Warsaw, Poland.

Whalley W.R., Watts C.W., Gregory A.S., Mooney S.J., Clark L.J., and Whitmore A.P., 2008. The effect of soil strength on the yield of wheat. Plant Soil, 306, 237-247.

Tan X., Kabzems R., and Chang S., X., 2006. Response of forest vegetation and foliar $\delta 13 \mathrm{C}$ and $\delta 15 \mathrm{~N}$ to soil compaction and forest floor removal in boreal aspen forest. Forest Ecol. Manag., 222, 450-458.

Zhao Y., Krzic M., Bulmer C.E., Schmidt G.M., and Simard S., 2010. Relative bulk density as a measure of compaction and its influence on tree height. Canadian J. Forest Res., 40, 1724-1735. 